\title{
Review of the Molecular Pharmacology of Losartan and Its Possible Relevance to Stroke Prevention in Patients with Hypertension
}

\author{
Javier Díez, MD, PhD \\ Division of Cardiovascular Sciences, Centre for Applied Medical Research, and Department of Cardiology \\ and Cardiovascular Surgery, University Clinic, School of Medicine, University of Navarra, Pamplona, Spain
}

\begin{abstract}
Background: The Losartan Intervention For Endpoint reduction in hypertension (LIFE) study found that a losartan-based regimen, compared with an atenololbased regimen, resulted in a significantly lower risk of stroke in hypertensive patients with left ventricular hypertrophy, despite similar reductions in blood pressure.

Objective: The purpose of this review was to examine the molecular and pharmacologic mechanisms that may be associated with the different outcomes observed in the LIFE study.

Methods: A PubMed/MEDLINE search of Englishlanguage articles (1990 to February 2006) with the terms angiotensin II antagonists or AIIAs or angiotensin receptor blockers or losartan or atenolol or beta blocker and terms including, but not limited to, atherosclerosis, left ventricular bypertrophy, carotid artery bypertrophy, fatty streaks, atrial fibrillation, arrhythmias, endothelial function, myocyte bypertrophy, myocardial fibrosis, platelet aggregation, tissue factor, plasminogen activator inhibitor-1, PAI-1, antiinflammatory, uric acid, or oxidative stress.
\end{abstract}

Results: Losartan's significant effect on stroke may be related to several possible mechanisms that are independent of blood-pressure reductions. These include improvements in endothelial function and vascular structure; decreases in vascular oxidative stress; reductions in left ventricular hypertrophy, reductions in myocardial fibrosis, or both; and modulation of atherosclerotic disease progression. Although some of these effects may be shared by other angiotensin II receptor antagonists (AIIAs), and perhaps other antihypertensive classes (eg, angiotensin-converting enzyme inhibitors), the ability of losartan to lower serum uric acid levels-a proposed independent risk factor for cardiovascular disease-appears to be a molecule-specific effect. Alternative explanations of the results of the LIFE study have also been hypothe- sized, including inappropriate choice of atenolol as an active comparator and differences in central pulse pressures between study groups.

Conclusions: This review of the literature suggests that losartan (and perhaps other AIIAs) may possess a number of properties, independent of its antihypertensive effects, that may be associated with decreased vulnerability of the plaque, myocardium, and blood. (Clin Ther. 2006;28:832-848) Copyright $(2006$ Excerpta Medica, Inc.

Key words: stroke, angiotensin II antagonists, losartan, atenolol, $\beta$-blockers, angiotensin II receptor, atherosclerotic plaque, hyperuricemia, arrhythmias, thrombosis, inflammation.

\section{INTRODUCTION}

Despite evidence of the importance of reducing blood pressure (BP), hypertension continues to be one of the most commonly occurring diseases in humans. ${ }^{1}$ Stroke is the most frequent complication in hypertensive patients. ${ }^{2}$ Indeed, hypertension has been considered an underlying factor in $\sim 70 \%$ of strokes. ${ }^{3}$ In 8 recently completed hypertension trials including 55,110 patients, 2057 strokes and 1603 myocardial infarctions (MIs) were reported. ${ }^{3}$ The relationship of stroke mortality to BP is strong and direct, regardless of age. ${ }^{4}$

In the Losartan Intervention For Endpoint reduction in hypertension (LIFE) study in hypertensive patients with left ventricular hypertrophy (LVH), the group of patients who received losartan had a $13.0 \%$ relative risk reduction in the occurrence of the primary composite end point of cardiovascular (CV) mortality,

Accepted for publication March 20, 2006.

doi:10.1016/j.clinthera. 2006.06.002

0149-2918/06/\$19.00

Printed in the USA. Reproduction in whole or part is not permitted. Copyright (c) 2006 Excerpta Medica, Inc. 
stroke (fatal and nonfatal), and MI $(P=0.021)$ and a $24.9 \%$ relative risk reduction in fatal or nonfatal stroke ( $P=0.001)$ compared with patients receiving an atenolol-based regimen. ${ }^{5}$ The LIFE study compared losartan-based therapy with atenolol-based therapy according to a double-blind, randomized, parallelgroup design in 9193 patients aged 55 to 80 years with hypertension (sitting BP, 160-200/95-115 mm Hg) and $\mathrm{LVH}$ ascertained by electrocardiography. ${ }^{5} \mathrm{~Pa}-$ tients were initially randomized to losartan $50 \mathrm{mg}$ plus placebo or atenolol $50 \mathrm{mg}$ plus placebo. After 2 months, hydrochlorothiazide (HCTZ) $12.5 \mathrm{mg}$ was added to the treatment regimen if the BP was not at or below goal BP (ie, $<140 / 90 \mathrm{~mm} \mathrm{Hg}$ ). If, at month 4 , the pressure was not adequately controlled, the dose of double-blind therapy was doubled to losartan $100 \mathrm{mg}$ or atenolol $100 \mathrm{mg}$ plus $12.5 \mathrm{mg}$ HCTZ. In patients whose BP was still not controlled at month 6 , additional open-label antihypertensive medication, including upward titration of HCTZ, was added to the treatment regimen. The dosage of HCTZ could be increased; additionally, or alternatively, any other antihypertensive drug (except angiotensin-converting enzyme inhibitors, angiotensin II type 1 receptor antagonists [AIIAs], or $\beta$-blockers) could be added at the discretion of the investigator. Outcomes favoring losartan were observed despite similar reductions in BP, suggesting that losartan's antistroke effects may have been independent of BP reduction. At the end of followup or last visit before a primary end point event, the mean sitting trough BP fell by $30.2 / 16.6 \mathrm{~mm} \mathrm{Hg}$ in the losartan group and by $29.1 / 16.8 \mathrm{~mm} \mathrm{Hg}$ in the atenolol group ( $P=0.015$ for systolic and $P=$ NS for diastolic). Overall, the time-averaged difference in mean arterial pressure was $0.1 \mathrm{~mm} \mathrm{Hg}$ in favor of atenolol, which was not statistically significant.

Atherothrombotic stroke was the most common form of stroke observed in the LIFE study, and the effects of losartan were greatest for this type of stroke. ${ }^{6}$ According to secondary analyses of LIFE data, patients who received a losartan-based treatment had significant reductions in the risk of atherothrombotic stroke (hazard ratio [HR], 0.72 [95\% CI, 0.59-0.88; $P=0.001])$ and fatal stroke (HR, $0.65[95 \% \mathrm{CI}$, $0.43-0.96] ; P=0.032$ ) compared with atenolol-based therapy. ${ }^{6}$ Similar risk reductions were observed for hemorrhagic and embolic stroke, but these stroke subtypes were not significantly different between the losartan and atenolol groups. ${ }^{6}$ This observation raises several questions. First, does losartan exert antithrombotic actions beyond lowering BP? Second, are these actions dependent on the angiotensin $\mathrm{AT}_{1}$ receptor? And third, are these actions common to all AIIAs?

Naghavi et $a^{7,8}$ proposed 3 factors as possible contributors to atherothrombotic events: plaques vulnerable to rupture, myocardium vulnerable to fatal arrhythmias, and blood prone to inflammation and thrombosis. Potentially, these factors may be targets of losartan's action. The purpose of this review was to examine the molecular and pharmacologic mechanisms that may be associated with the different outcomes observed in the LIFE study.

\section{METHODS}

A PubMed/MEDLINE search of English-language articles (1990 to February 2006) was used to identify possible pharmacologic mechanisms of action. Searches were conducted by combining the terms angiotensin II antagonists or AIIAs or angiotensin receptor blockers or losartan or atenolol or beta blocker with terms including, but not limited to, atherosclerosis, left ventricular bypertrophy, carotid artery bypertrophy, fatty streaks, atrial fibrillation, arrbythmias, endothelial function, myocyte bypertrophy, myocardial fibrosis, platelet aggregation, tissue factor, plasminogen activator inbibitor-1, PAI-1, anti-inflammatory, uric acid, or oxidative stress. Articles describing pathophysiologic effects of angiotensin II (AII) and molecular mechanisms of pharmacologic action of losartan pertinent to the LIFE study were, in the opinion of this author, appropriate for review.

\section{LOSARTAN AND VULNERABLE PLAQUE}

Atherosclerosis can be viewed as a specialized type of chronic inflammation. ${ }^{9}$ Atherogenic factors promote the attachment and proliferation of mononuclear cells on the luminal surface of the arterial wall; these cells eventually migrate across the endothelium and accumulate in the intima. ${ }^{10}$ In the presence of oxidized low-density lipoprotein cholesterol (LDL-C), monocytes are converted to activated macrophages and take up lipoprotein particles, resulting in their conversion to foam cells. ${ }^{11}$ The continued formation of foam cells and their accumulation in the intima, along with the migration of smooth muscle cells, lead to the development of a fatty streak. ${ }^{9}$ The fatty streak progresses to fibrofatty and fibrous plaques, which are characterized by recruitment of extracellular matrix components 
and increased deposition of intracellular and extracellular lipid. ${ }^{9}$ In the experience of this author, unstable plaques (which are prone to rupture) are characterized by a thin fibrous cap, a high foam-cell content, and expression of various metalloproteinases.

\section{Endothelial Dysfunction}

Endothelial dysfunction is an early feature of atherosclerosis and contributes to the atherosclerotic process by promoting abnormal vasomotion, infiltration of inflammatory cells, and increased coagulation. ${ }^{12}$ AII promotes endothelial dysfunction through several mechanisms, one of which is inactivation of nitric oxide. ${ }^{13}$ In a study of 25 patients with atherosclerotic disease, a 20-minute infusion of losartan $250 \mu \mathrm{g} / \mathrm{min}$ improved coronary vasomotion during flow-mediated dilation in response to adenosine from a mean (SD) of $5.6 \%(1.5 \%)$ to $8.9 \%(1.8 \%)(P=0.02) .{ }^{14}$ Similarly, in 31 patients with atherosclerosis, treatment with oral losartan 25 to $50 \mathrm{mg}$ for 8 weeks improved brachial artery vasodilation (mean [SD], $1.4 \%[0.9 \%]$ to $3.2 \%$ $[0.8 \%] ; P=0.03)$ and significantly increased serum nitrogen oxide levels (mean [SD], 21.6 [1.7] to 26.7 $[2.4] \mu \mathrm{mol} / \mathrm{L} ; P=0.008) .{ }^{15}$ Six weeks of treatment with candesartan $16 \mathrm{mg} / \mathrm{d}$ has also been associated with an improved forearm blood flow response during reactive hyperemia in a randomized, double-blind study of 47 hypercholesterolemic patients with LDL-C $>160 \mathrm{mg} / \mathrm{dL}$ (approximate change, $31 \%$ vs $5 \%$ with placebo; $P<$ $0.05) .{ }^{16}$ A similar improvement in flow-mediated dilator response to hyperemia with candesartan $16 \mathrm{mg} / \mathrm{d}$ for 2 months was noted in a randomized, double-blind, placebo-controlled crossover study in 45 patients with mild to moderate hypertension. ${ }^{17}$ Compared with placebo, candesartan was associated with a significant increase in flow-mediated dilator response from a mean (SD) of $5.17 \%(0.24 \%)$ at baseline to $6.22 \%$ $(0.26 \%)$ at the end of 2 months $(P<0.001) .^{17}$

It seems possible that another mechanism by which AII may promote endothelial dysfunction is through augmented expression of endothelial adhesion molecules and, in turn, stimulation of leukocyte adhesion to endothelial cells. For instance, it has been reported that AII upregulates intercellular adhesion molecule (ICAM-1) expression by cultured human vascular endothelial cells in vitro derived from umbilical cord veins and stimulates in vitro and in vivo soluble ICAM-1 release. ${ }^{18}$ In a separate series of experiments involving patients with essential hypertension, treat- ment for 4 weeks with losartan $50 \mathrm{mg} / \mathrm{d}$ (Figure 1, $\mathrm{n}=5$ ), but not treatment with atenolol $50 \mathrm{mg}$ QD ( $\mathrm{n}=$ 4 [data not shown in figure]), was found to blunt the ICAM-1 response to AII. ${ }^{18}$

An early event in atherosclerosis is hypertrophy of the arterial wall, ${ }^{19}$ and a reliable surrogate measurement is carotid intima-media thickness. ${ }^{20,21} \mathrm{In}$ rabbits fed high-cholesterol diets, administration of losartan (25 mg/d for 10 weeks) was associated with significant reductions in intimal proliferation and the ratio of intima to media in the aorta (both, $P<0.01$ vs high-cholesterol diet alone). ${ }^{22}$ In hypertensive patients who were treated for 1 year with losartan, significant reductions in mean (SD) media width to lumen diameter of gluteal arteries (from $8.4 \%[0.4 \%]$ at baseline to $6.7 \%[0.3 \%]$ at 1 year; $P<0.01$ ) were observed, whereas treatment with atenolol was not associated with a significant change (from $8.3 \%$ [0.3\%] at baseline to $8.8 \%[0.5 \%]$ at the end of treatment). ${ }^{23}$ The study involved obtaining gluteal subcutaneous biopsies under local anesthesia from 19 patients randomly assigned to treatment with $50 \mathrm{mg}$ of losartan or atenolol in a double-blind fashion. Similar improvements in vascular structure in hypertensive patients have also been reported with irbesartan. ${ }^{24}$

\section{Vascular Oxidative Stress}

Atherosclerosis is initiated and amplified by vascular oxidative stress. ${ }^{25}$ AII has been implicated in this process through a variety of mechanisms involving alteration of lipid synthesis, lipid oxidation, and lipid entry into susceptible endothelium.

AII $\left(10^{-7} \mathrm{M}\right.$ for 18 hours at $\left.37^{\circ} \mathrm{C}\right)$ has been shown to increase in vitro cellular cholesterol biosynthesis (measured by ${ }^{3} \mathrm{H}$ acetate incorporation into cholesterol) by $44 \%, 34 \%$, and $30 \%$, respectively, in human monocyte-derived macrophages, in mouse peritoneal macrophages, and in J-774A.1 macrophage-like cell line. ${ }^{26}$ This effect can be completely attenuated by losartan at a concentration of $10^{-5} \mathrm{M} .^{26}$ In addition, AII enhances LDL-C oxidation by stimulating the activity of nicotinamide adenine dinucleotide phosphate oxidases in vascular smooth muscle cells (VSMCs) and endothelial cells. ${ }^{27-29}$ In animal models of atherosclerosis, losartan was associated with a significant attenuation of aortic atherosclerotic lesions $(P=$ $0.001),{ }^{30}$ a significant reduction in LDL-C oxidation in apolipoprotein(E)-deficient mice after 10 weeks of treatment $(P<0.005$ vs placebo $),{ }^{31}$ and a significant 


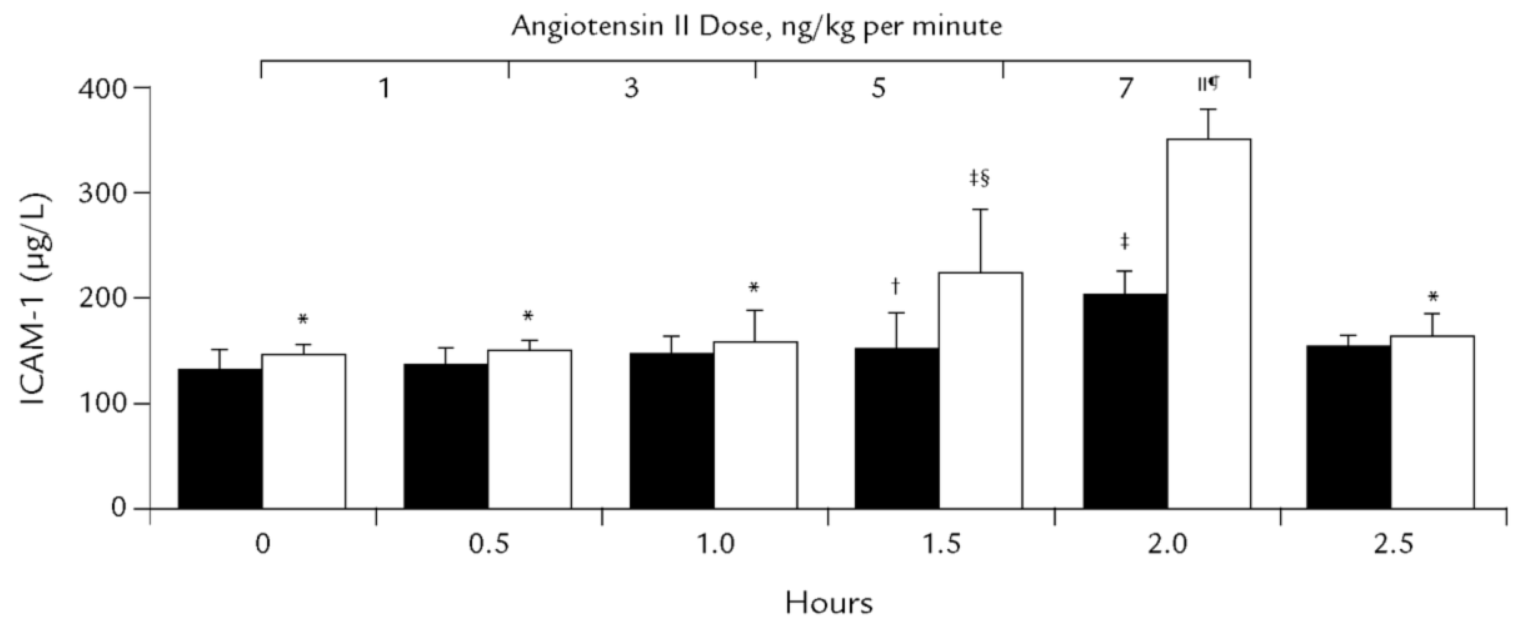

Figure 1. Effect of angiotensin II infusion (at an initial rate of $1 \mathrm{ng} / \mathrm{kg}$ per minute, increased every 30 minutes by $2 \mathrm{ng} / \mathrm{kg}$ per minute) on circulating intercellular adhesion molecule (ICAM-1) levels in patients with essential hypertension $\left(\mathrm{n}=5\right.$ ) before and after 4 weeks on placebo or losartan $50 \mathrm{mg} / \mathrm{d}$. ${ }^{*} P<0.05$ versus baseline; $\uparrow P<0.003$ versus time; $\ddagger P<0.002$ versus time $0 ; \S P<0.003$ versus baseline; $\| P<0.0001$ versus time $0 ; P<0.0001$ versus baseline. Reproduced with permission. ${ }^{18}$

reduction in the susceptibility of LDL-C to in vitro oxidation $(P<0.05)$ in hypercholesterolemic monkeys at the end of 6 weeks of treatment. ${ }^{32}$ In a randomized, prospective, crossover study, hypertensive patients ( $\mathrm{n}=40$ ) with type 2 diabetes who received losartan $50 \mathrm{mg} / \mathrm{d}$ for 16 weeks experienced significant reductions in LDL-C oxidation (determined by malondialdehyde [MDA] with the thiobarbituric acid-reactive substances assay with and without cupric sulfate) after 16 weeks $(P=0.001) .{ }^{33}$ Values for LDL-oxidation with cupric sulfate decreased from $40.3 \mathrm{nmol} \mathrm{MDA} / \mathrm{mg}$ protein at baseline to $34.6 \mathrm{nmol} \mathrm{MDA} / \mathrm{mg}$ protein after losartan $(P=0.001)$.

Lectin-like oxidized low-density lipoprotein (Ox-LDL) receptor (LOX-1) expression is upregulated by AII in cultured human coronary artery endothelial cells and in primary cultures of human umbilical vein endothelial cells. ${ }^{34,35}$ In hypercholesterolemic rabbits, losartan $25 \mathrm{mg} / \mathrm{kg}$ daily for 10 weeks was associated with attenuated aortic intimal proliferation $(P<0.01)$ and markedly decreased LOX-1 messenger RNA (mRNA, $P<0.01$ ), and LOX-1 expression determined immunohistochemically (no statistical com- parison given). ${ }^{36}$ In addition, losartan $50 \mathrm{mg} / \mathrm{d}$ for 4 weeks was associated with Ox-LDL uptake, as indicated by a $78 \%$ decrease in Ox-LDL cell association and a $21 \%$ reduction in Ox-LDL degradation, as well as a reduction in the expression of the Ox-LDL receptor CD36 by $54 \% .37$

Collectively, the above studies indicate a key role for AII in the initiation and magnification of the atherosclerotic process. Although likely, it is not clear whether AII's effects on this process are mediated by the $\mathrm{AT}_{1}$ receptor or whether other AIIAs have mechanisms of action similar to those of losartan.

\section{LOSARTAN AND VULNERABLE MYOCARDIUM}

It is common knowledge that cardiac arrhythmias occur frequently in hypertensive patients, and that the presence and complexity of arrhythmias may influence the morbidity and mortality of patients, especially those in relation to the occurrence of stroke. Along with diastolic dysfunction of the left ventricle and changes in left atrial size and function, LVH emerges as the main risk factor for arrhythmias in patients with hypertension. ${ }^{38}$ In fact, it has been shown that LVH is 
associated with proarrhythmic repolarization changes and increased occurrence of atrial fibrillation and ventricular arrhythmias. ${ }^{39-41}$

\section{Myocardial Fibrosis}

LVH is characterized by increased extracellular matrix deposition (ie, myocardial fibrosis) and increased myocyte size (ie, myocyte hypertrophy). Myocardial fibrosis results from increased accumulation of fibrillar collagen types I and III throughout the septum and free wall of the left ventricle $e^{42-44}$ and is thought to promote abnormalities of cardiac function, coronary reserve, and electrical activity. ${ }^{45}$ In particular, it has been reported that hypertensive patients with $\mathrm{LVH}$ and arrhythmias exhibited higher myocardial collagen tissue deposition and left ventricular mass than patients without arrhythmias. ${ }^{45}$

Various lines of evidence suggest that systemically produced AII, locally produced AII, or both may participate in the development of myocyte hypertrophy and myocardial fibrosis that accompany hypertension via activation of the $\mathrm{AT}_{1}$ receptor in cardiac myocytes ${ }^{46}$ and fibroblasts. ${ }^{47}$ Therefore, losartan might exert an antiarrhythmic effect by inducing regression of $\mathrm{LVH}$ and reduction of myocardial fibrosis. This is support- ed by the fact that significant reductions in LVH, myocardial fibrosis, or both have been reported to occur with losartan in hypertensive patients, ${ }^{48-53}$ hypertensive animals, ${ }^{54-56}$ rat models of hypertension, ${ }^{57-59}$ and animal models of MI (all, $P<0.05$ ). ${ }^{60-64}$

Further studies have found that these effects were evident at doses ineffective for reducing $\mathrm{BP}^{65}$ and in animals in which BP was not normalized. ${ }^{66,67}$ This effect of losartan was reproduced in hypertensive patients in whom reduction of collagen synthesis and myocardial fibrosis was associated with decreased myocardial stiffness (Figure 2). ${ }^{51,68}$ Additional support came from the LIFE study, in which all patients had documented LVH. Compared with atenolol-treated patients, patients who received losartan had significantly greater reductions in left ventricular mass index (LVMI) $(-21.7$ [21.8] vs $-17.7[19.6] \mathrm{g} / \mathrm{m}^{2} ; P=0.021$ ) and $\mathrm{LVH}$ as determined by Sokolow-Lyon voltage on electrocardiogram $(-2.5$ vs $-0.7 \mathrm{~mm} ; P<0.001)$ or Cornell voltage-duration product $(-200 \mathrm{vs}-69 \mathrm{~mm} \cdot \mathrm{ms} ; P<$ 0.001 ), despite similar reductions in BP. ${ }^{69,70}$

Other AIIAs have shown similar actions to losartan with regard to reduction of myocardial fibrosis. ${ }^{71-78}$ Valsartan has been reported to inhibit myocardial fibrosis (interstitial collagen content) in post-MI rats
A

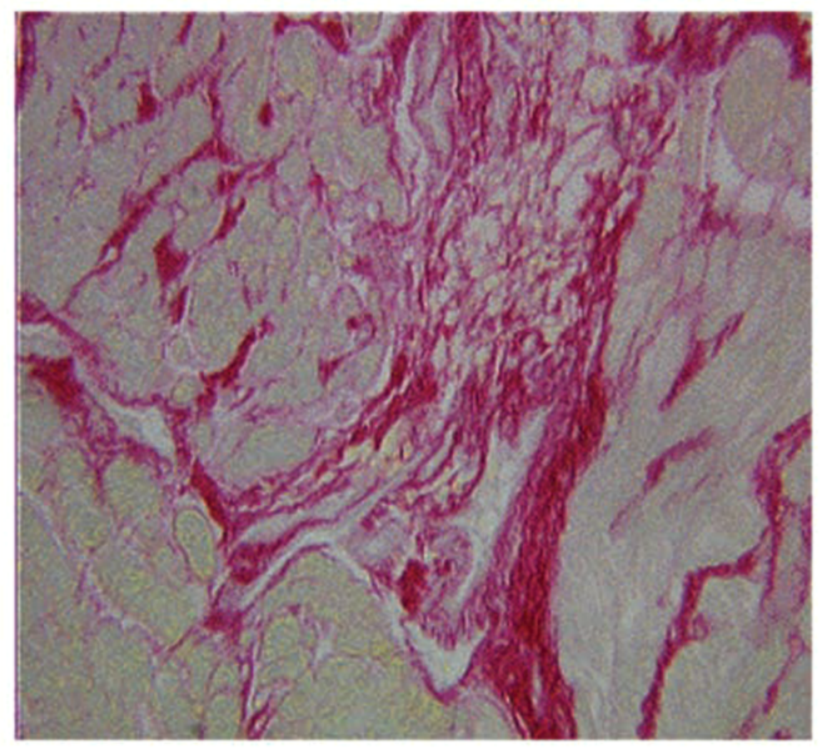

B

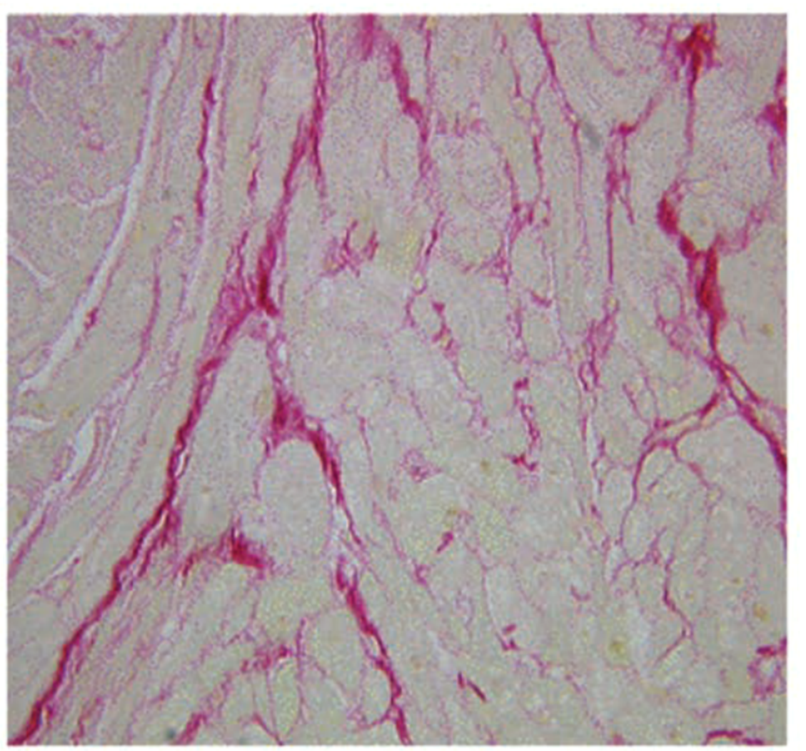

Figure 2. Histologic section of myocardial specimen biopsy from a hypertensive patient with severe myocardial fibrosis. The image used picrosirius red stain and $20 \times$ magnification. (A) Before chronic treatment with losartan. (B) After losartan. 
$(P<0.05 \text { vs placebo })^{71}$; however, the role of BP changes is unclear. Similarly, candesartan has been reported to reduce collagen synthesis in cell culture ${ }^{79}$ and to reduce myocardial fibrosis in animal models. ${ }^{73-78}$ Although evidence for the action of candesartan or valsartan in humans is limited, a randomized, double-blind study comparing valsartan with atenolol found that treatment with valsartan was associated with significant regression of LVH in largely untreated patients with hypertension. ${ }^{80}$ Patients who received valsartan exhibited a decrease in mean (SD) LVMI (from 127 [23] g/m² at baseline to $106[25] \mathrm{g} / \mathrm{m}^{2}$ at 8 months; $P<0.001$ ). Similarly, atenolol-treated patients experienced a significant decrease in mean (SD) LVMI (from 127 [25] g/m² at baseline to $117[27] \mathrm{g} / \mathrm{m}^{2}$ at 8 months; $P<0.009$ ).

\section{Alternative Mechanisms}

The arrhythmogenicity of AII may be mediated through alternative mechanisms. In fact, in guinea-pig isolated atria, AII increased norepinephrine release induced by electrical field stimulation (55\% maximal augmentation at $\left.10^{-6} \mathrm{~mol} / \mathrm{L} \mathrm{AII}\right)$, and the effects of $10^{-6} \mathrm{~mol} / \mathrm{L}$ and $10^{-7} \mathrm{~mol} / \mathrm{L}$ AII were completely inhibited by $10^{-6} \mathrm{~mol} / \mathrm{L}$ losartan. ${ }^{81}$ Thus, given the evidence that norepinephrine may have proarrhythmogenic effects, ${ }^{82}$ it is possible that losartan may have antiarrhythmic properties via inhibition of norepinephrine release in cardiac sympathetic nerves.

Preliminary experimental in vitro data obtained using guinea-pig ventricle and isolated guinea-pig ventricular myocytes suggest that losartan inhibits cardiac delayed rectifier $\mathrm{K}^{+}$currents, thus providing a molecular basis for the modification of the atrial and ventricular action potentials. ${ }^{83}$ This property may have relevance when considering the antiarrhythmic properties of losartan, given the evidence that losartan reduces QT dispersion, which is an electrocardiographic measure of ventricular repolarization and is also a risk marker for ventricular tachyarrhythmias. ${ }^{84}$ This study analyzed QT intervals (calculated by a single, blinded investigator using standard 12-lead electrocardiography) in a total of 90 heart-failure patients at baseline and after active treatment with losartan $(n=47)$ or captopril $(\mathrm{n}=43)$. QT dispersion $\left(\mathrm{QT}_{\mathrm{d}}\right.$, defined as the difference between maximum and minimum QT intervals [ie, beginning of the QRS complex to end of the T wave]) increased in patients receiving captopril (from mean [SD] 64 [25] $\mathrm{ms}$ at baseline to 74 [25] $\mathrm{ms}$ at end of study; $P=0.008$ ) but not in patients receiving losartan (from mean [SD] 60 [21] ms at baseline to 60 [22] ms at end of study; $P=\mathrm{NS})$. The difference between groups was significant $(P=0.01)$.

\section{LOSARTAN AND BLOOD VULNERABILITY Inflammation}

Rupture of the sclerotic plaque and the associated formation of thrombus are the most important mechanisms leading to complications associated with atherosclerosis. ${ }^{85}$ AII promotes inflammation via induction of nuclear translocation of nuclear factor $\kappa \mathrm{B}$ (NF- $\kappa \mathrm{B})$, thereby upregulating expression of inflammatory $\mathrm{cy}-$ tokines in monocytes, endothelial cells, and VSMCs. ${ }^{86,87}$ In aortic segments from hypercholesterolemic rabbits, losartan was associated with significantly reduced activation of NF- $\mathrm{kB}$ compared with a control group on a high-cholesterol $\operatorname{diet}(P<0.05[\mathrm{n}=4$ in each group $])$; it was postulated that this might have been the result of inhibiting degradation of its inhibitor, I $\kappa-\mathrm{B} \alpha{ }^{88} \mathrm{In}$ addition to upregulating NF- $\mathrm{kB}$, AII induces monocyte chemotaxis by upregulating monocyte chemoattractant protein 1 (MCP-1) and $\mathrm{C}-\mathrm{C}$ chemokine receptor 2 (MCP-1 receptor). ${ }^{89-91}$ Losartan has been reported to completely inhibit the binding of monocytes to human aortic endothelial cells induced by AII in culture $(P<0.05))^{92}$ In addition, losartan inhibits basal MCP-1 expression, ${ }^{93,94}$ as well as LDL-Cstimulated MCP-1 expression. ${ }^{93}$ Losartan therapy reduced circulating levels of MCP-1 in hypercholesterolemic monkeys after 6 weeks (from $\sim 105$ to $70 \mathrm{ng} / \mathrm{mL} ; P<0.05) .{ }^{32}$ Eighteen healthy volunteers who received losartan $(50 \mathrm{mg} / \mathrm{d}$ for 6 weeks $)$ in a randomized, double-blind, crossover study experienced a significant reduction in MCP-1 concentration (from 560 to $423 \mathrm{ng} / \mathrm{mL}$ at week $6 ; P<0.01) .{ }^{95}$ Similar actions of candesartan and irbesartan have been reported in hypertensive patients or healthy volunteers, ${ }^{17,96}$ and would suggest that some of the actions of losartan on macrophage chemotaxis may be mediated by the $\mathrm{AT}_{1}$ receptor and common to the AIIAs.

Arachidonic acid metabolism plays an important role in acute ischemic syndromes affecting the coronary or cerebrovascular territory, as reflected by biochemical measurements of eicosanoid biosynthesis and the results of inhibitor trials in these settings. ${ }^{97}$ In particular, the clinical efficacy of low-dose aspirin in reducing the short-term complications of acute MI and acute ischemic stroke, as well as in preventing vascular recurrences, has focused attention on the cyclooxygenase 
(COX) pathway of arachidonic acid metabolism and its bioactive products. ${ }^{98}$ Experimental and clinical tools developed during the past 10 years have allowed one to hypothesize a role for COX-2-derived prostanoids and matrix metalloproteinases in atherosclerotic disease progression and its thrombotic complications. ${ }^{99}$

AII has been found to upregulate COX-2 mRNA in vitro in rat VSMCs, ${ }^{100}$ thereby increasing prostaglandin synthesis, an effect that was completely blocked by losartan. ${ }^{100}$ Similarly, AII upregulates the expression of both COX-2 mRNA (6.5-fold increase at 3 hours; $P<0.001)$ and protein and stimulates the production of COX-2-dependent prostaglandins in cultured human aortic VSMCs in vitro. ${ }^{101}$ Pretreatment of VSMCs with losartan ( $1 \mu \mathrm{M}$ for 30 minutes $)$ in vitro attenuated the effects of AII on the expression of the COX-2 protein (without altering the expression of COX-1) and also inhibited the AII-stimulated release of prostaglandin $\mathrm{E}_{2}\left(\mathrm{PGE}_{2}\right) .{ }^{101} \mathrm{~A}$ study in patients with symptomatic carotid artery stenosis treated with irbesartan or chlorthalidone for 4 months before endarterectomy has also reported that irbesartan was associated with a decrease in inflammation and inhibition of COX-2/ $\mathrm{PGE}_{2}$-dependent synthase expression in atherosclerotic plaque. ${ }^{102}$ The authors suggested that this effect may contribute to plaque stabilization.

\section{Thrombosis}

Tissue factor (TF) initiates coagulation through binding to factor VII. ${ }^{103}$ In situ hybridization and immunohistochemistry techniques (using a specific riboprobe for TF mRNA and a polyclonal antibody directed against human TF protein) have identified TF-producing cells in normal human vessels and atherosclerotic plaques. ${ }^{104}$ Wilcox et al ${ }^{104}$ reported the absence of TF mRNA and protein in endothelial cells lining normal internal mammary artery and saphenous vein samples, although TF was synthesized in scattered cells present in the tunica media as well as in fibroblast-like adventitial cells surrounding vessels. In contrast, vessels with atherosclerotic plaques contained many cells synthesizing TF mRNA and protein, including macrophages present as foam cells and monocytes adjacent to the cholesterol clefts. ${ }^{104}$ AII has been reported to increase TF expression in cultured endothelial cells and VSMCs. ${ }^{105,106}$ Losartan has been reported to reduce expression of TF in leukocytes from healthy volunteers ${ }^{107}$ and in cultured VSMCs exposed to AII. ${ }^{108}$ In addition, several AIIAs (ie, irbesartan, candesartan, valsartan) have been shown to reduce TF expression in hypertensive patients, transgenic rats, or human cultured monocytes. ${ }^{109-111}$

AII also promotes coagulation by inhibiting the fibrinolytic system by inducing plasminogen activator inhibitor-1 (PAI-1) in the vasculature. ${ }^{112}$ Conflicting data suggest that losartan may mediate antifibrinolytic activity via reduction of PAI-1 expression and activity, ${ }^{113-117}$ and other reports suggest that losartan may inhibit fibrinolysis by alternate actions through prevention of platelet aggregation (Figure 3). ${ }^{118,119}$ The different observations about PAI- 1 activity and expression may reflect the manner in which the analyses were conducted, such as timing of sample collection and duration of treatment. ${ }^{113}$ Reduction of PAI-1 levels by candesartan, valsartan, and irbesartan would, however, suggest that AII-mediated inhibition of fibrinolysis may be affected by the $\mathrm{AT}_{1}$ receptor. ${ }^{17,109,120,121}$

It is widely acknowledged that transformation of arachidonic acid into prostaglandins such as prostaglandin $\mathrm{F}_{2 \alpha}\left(\mathrm{PGF}_{2 \alpha}\right)$ and thromboxane $\mathrm{A}_{2}\left(\mathrm{TXA}_{2}\right)$ is associated with increased platelet aggregation. Altered

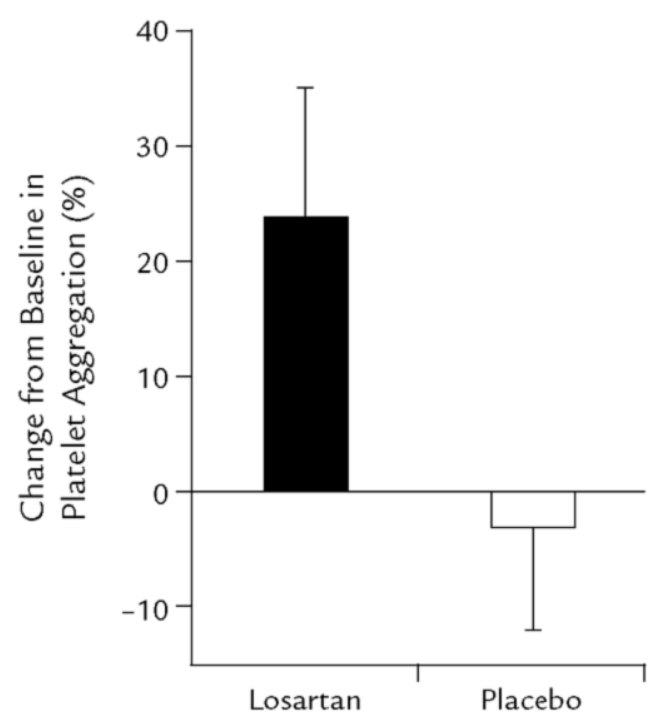

Figure 3. Increase in the extent of platelet aggregation at median effective concentration producing a response of $50 \%$ of the maximal response, mediated by a selective thrombin receptor agonist in 9 hypertensive patients administered losartan $50 \mathrm{mg} / \mathrm{d}$ or placebo for 4 weeks. Adapted with permission. ${ }^{119}$ 
platelet function plays a critical role in the development of thrombi. TXA 2 , the main product of platelet arachidonic acid metabolism, is a potent inducer of platelet aggregability. ${ }^{122}$ Platelet shape change is an early phase of platelet activation that precedes platelet aggregation. AII has been found to induce platelet shape change in human platelets from healthy volunteers, as suggested by a significant increase in median platelet volume $(P<0.004) .{ }^{123}$ In $\sim 57 \%$ of subjects $(\mathrm{n}=8)$ who experienced a marked increase in median platelet volume $(>0.4 \mathrm{fL})$, losartan significantly inhibited platelet shape change induced by AII (from $5.85 \mathrm{fL}$ with AII alone to $5.55 \mathrm{fL}$ after AII plus losartan after 10 minutes; $P<0.008)$. ${ }^{123}$ Similar changes were also induced by the TXA 2 analogue U46619.123 Furthermore, several studies have reported the inhibition of U46619-induced platelet aggregability by losartan in human, canine, or rat platelets in vitro. ${ }^{124-131}$ The inhibitory effect of losartan on platelet aggregability appears to be greater with the parent compound than with its metabolite EXP3174. 124,126,127 Losartandependent inhibition of $\mathrm{PGF}_{2 \alpha}$ formation has also been reported in hypertensive patients after oral administration of losartan $100 \mathrm{mg}$ (Figure 4). ${ }^{132}$ Irbesartan also inhibited the $\mathrm{TXA}_{2}$ receptor in platelets, but candesartan and valsartan appeared to have little or no effect on platelet aggregability. ${ }^{128-130}$

\section{EMERGING ASPECTS \\ Serum Uric Acid}

Hyperuricemia is common in patients with CV and kidney disease. ${ }^{133}$ In the general population, hypertensive patients, and those with preexisting CV disease, serum uric acid (SUA) may represent an important predictor of CV events. ${ }^{134}$ However, the link between SUA and risk of CV events is controversial (for detailed review, see Alderman and Aiyer ${ }^{135}$ ). Studies have reported that SUA is associated with the activation of circulating platelets, ${ }^{136}$ upregulation of MCP-1, ${ }^{137}$ impaired endothelial nitric oxide release, ${ }^{138}$ VSMC proliferation, ${ }^{139-141}$ and induction of COX-2, TXA, and other cytokines. ${ }^{139-142}$ In a multivariate analysis of patients who had experienced ischemic stroke, high SUA was associated with poor outcome (ie, death or life in care) and with subsequent vascular events (ie, MI, ischemic stroke, or vascular death), based on data from 3731 patients (SUA measurements were available in 2498). ${ }^{143}$

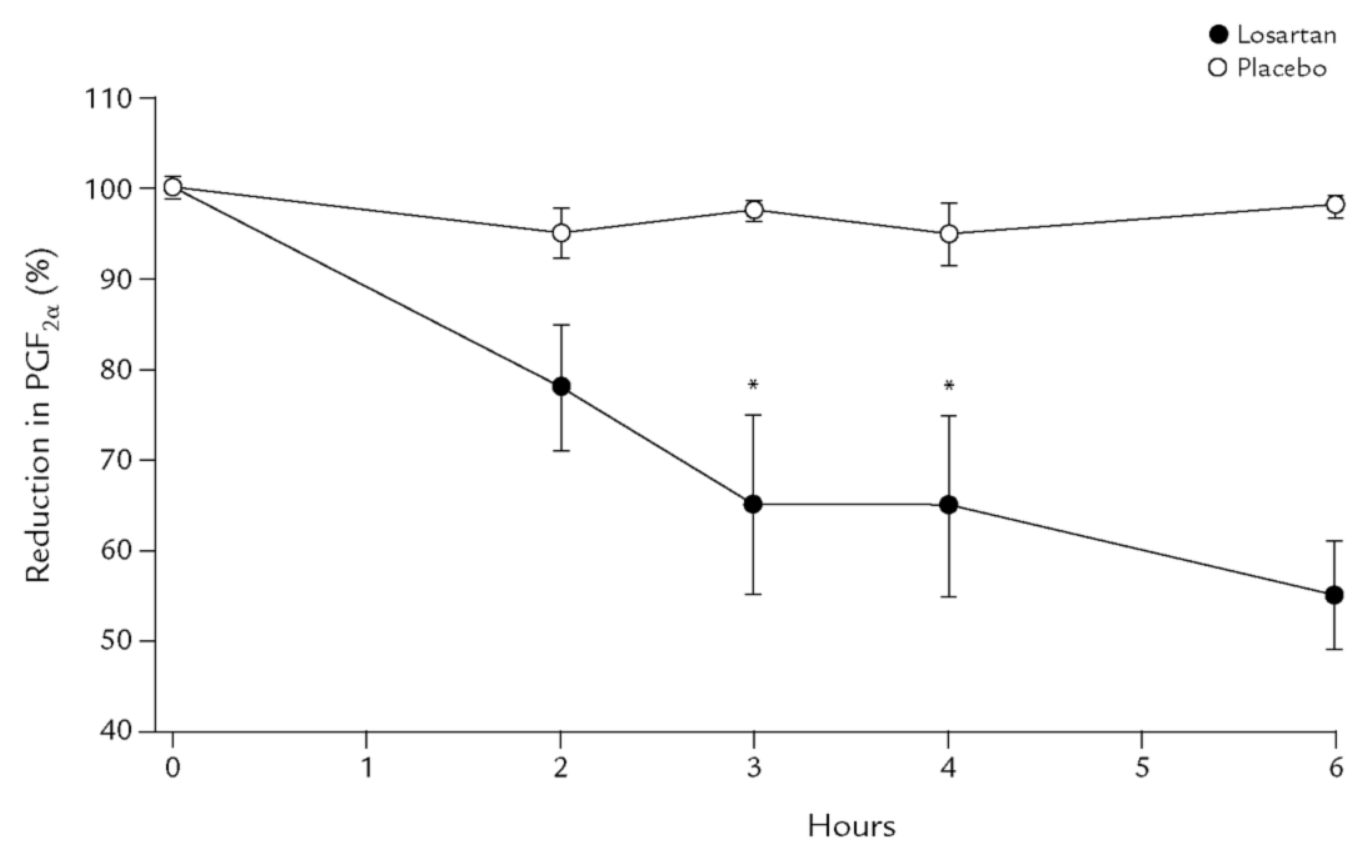

Figure 4. Losartan-dependent inhibition of prostaglandin $F_{2 \alpha}\left(P F_{2 \alpha}\right)$ formation in serum samples of 5 patients after oral administration of losartan $100 \mathrm{mg}$ or placebo. PGF $_{2 \alpha}$ was measured by enzyme-linked immunosorbent assay. ${ }^{*} P<0.01$ versus placebo. Reproduced with permission. ${ }^{132}$ 
Losartan was reported to decrease SUA in healthy Japanese male subjects in a dose-dependent manner, with single doses ranging from 25 to $200 \mathrm{mg} .{ }^{144} \mathrm{In}$ that study, SUA measured at 4 hours after administering single oral doses of losartan 25, 50,100, or $200 \mathrm{mg}$ $(\mathrm{n}=6)$, or placebo $(\mathrm{n}=3)$, was decreased from baseline by a mean of $0.32 \mathrm{mg} / \mathrm{dL}$ (with losartan $25 \mathrm{mg}$ ), $0.77 \mathrm{mg} / \mathrm{dL}$ (with losartan $50 \mathrm{mg}$ ), $1.25 \mathrm{mg} / \mathrm{dL}$ (with losar$\tan 100 \mathrm{mg}$ ), and $1.33 \mathrm{mg} / \mathrm{dL}$ (with losartan $200 \mathrm{mg}$ ).

Losartan has been found to produce a uricosuric effect. ${ }^{145}$ Data from Sweet et al ${ }^{146}$ suggest that the parent molecule, not its active metabolite EXP3174, is the active agent blocking uric acid absorption. Furthermore, the effect of losartan on SUA does not appear to be shared with other members of the AIIA class. ${ }^{147-149}$ Recently, the LIFE study reported a possible association of baseline SUA with MI, stroke, or CV death (HR, 1.024 per $10 \mu \mathrm{mol} / \mathrm{L}$ [95\% CI, 1.0171.032]; $P<0.001) .{ }^{150}$ Although SUA levels increased in both the losartan and atenolol groups, patients who were treated with losartan had a significant attenuation of the increase in SUA from baseline. ${ }^{150}$ The increase from baseline in mean (SD) SUA was greater in atenolol-treated subjects than in losartan-treated subjects (44.4 [72.5] vs $17.0[69.8] \mu \mathrm{mol} / \mathrm{L} ; P<0.001)$. The association of SUA with CV events was significant in women (HR, 1.025 [95\% CI, 1.013-1.037]; $P<0.0001)$ and remained so after adjustment for the Framingham risk score (HR, 1.013 [95\% CI,
1.00-1.025]; $P<0.046) .{ }^{150}$ However, the relationship between baseline SUA and CV events was not significant in men (HR, 1.009 [95\% CI, 0.998-1.019]). SUA as a time-varying covariate was also associated with events in the entire population $(P<0.001)$; this association was strong in women $(P<0.001)$, but was not present in men $\left(P=\right.$ NS). ${ }^{150}$ The underlying reasons for this apparent gender difference are unclear, however.

\section{The Losartan Metabolite EXP3179}

Given the differences in the effects of losartan on platelet aggregability, compared with other AIIAs, losartan's metabolite has been identified and its effects on COX-2 and its role in platelet aggregability investigated. ${ }^{132}$ Losartan is metabolized by the liver primarily by the cytochrome P450 (CYP) 2C (CYP2C) enzymes, with some additional involvement of the CYP3A enzymes (Figure 5). ${ }^{151}$ Losartan is biotransformed to the active carboxylic acid derivative EXP3174, which has been shown to be 40 times more potent at blocking the $\mathrm{AT}_{1}$ receptor than losartan. ${ }^{152}$ EXP3179, an intermediate aldehyde compound in the metabolism of losartan, has also been identified ${ }^{151}$ and reported to have extremely low (if any) affinity for the $\mathrm{AT}_{1}$ receptor. ${ }^{132}$ Plasma levels of EXP3179 after administration of losartan have been reported to increase at 2 hours and peak at 3 to 5 hours before disappearing at $\sim 6$ hours postadministration. ${ }^{132}$

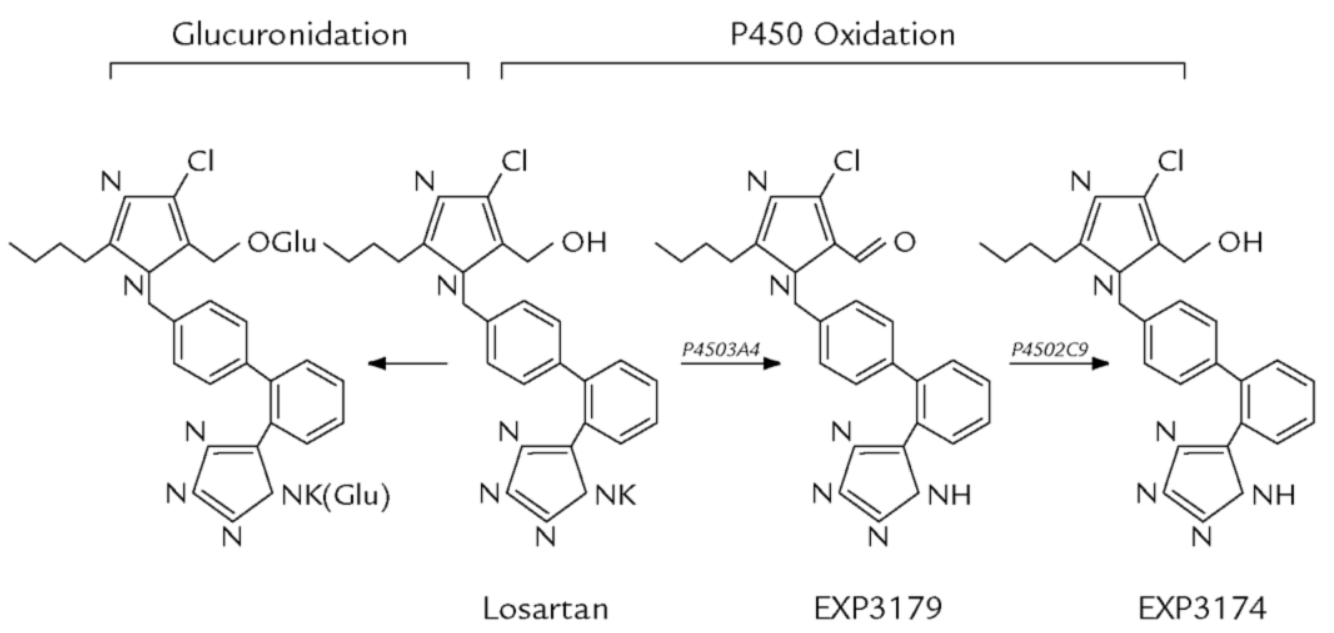

Figure 5. Schema for the cytochrome P450 oxidative biotransformation of losartan to its active carboxylic acid metabolite, EXP3174, and its aldehyde intermediate, EXP3179. 
Recently, Kramer et al ${ }^{132}$ reported that EXP3179 had anti-inflammatory activities that were independent of the $\mathrm{AT}_{1}$ receptor and were mediated by regulation of COX-2 mRNA expression. EXP3179 was thought to elicit COX-2 inhibitory properties by blocking COX-2 mRNA upregulation and $\mathrm{PGF}_{2 \alpha}$ synthesis induced by AII and bacterial lipopolysaccharide (LPS), an $\mathrm{AT}_{1}$ receptor-independent proinflammatory stimulus, in human endothelial cells. ${ }^{132}$ EXP3179 also prevented upregulation of ICAM-1 induced by LPS in these cells. ${ }^{132}$ Finally, EXP3179 abolished platelet aggregation induced by arachidonic acid and U46619. ${ }^{132}$ Importantly, treatment of hypertensive patients with a single dose of losartan $100 \mathrm{mg}$ resulted in a decrease in platelet aggregability at $\sim 6$ to 8 hours after administration, which coincided with peak plasma concentrations of EXP3179.132 The anti-inflammatory and antiaggregatory effects of losartan appear to be partially independent of its blockade of the $\mathrm{AT}_{1}$ receptor and may be related to alternative mechanisms elicited by its metabolite, EXP3179.

Research using the endothelium of intact rat aorta and endothelial cells in vitro has found that EXP3179 stimulates endothelial nitric oxide synthase (eNOS) phosphorylation and suppresses tumor necrosis factor$\alpha$-induced endothelial cell apoptosis by activating the vascular endothelial growth factor receptor-2 signaling pathway. ${ }^{153}$ The magnitude for EXP3179-stimulated phosphorylation of eNOS was much greater than that of EXP3174, and the median effective concentration producing a response of $50 \%$ of the maximal response (EC50) was significantly lower (mean [SD] -logEC50, $8.2[0.1]$ vs $5.4[0.2] \mathrm{mol} / \mathrm{L}$, respectively), suggesting an $\mathrm{AT}_{1}$ receptor-independent beneficial effect of the losartan metabolite EXP3179 on the endothelium.

Finally, a study identified EXP3179 as a partial peroxisome proliferator-activated receptor $\gamma$ (PPAR- $\gamma$ ) agonist. ${ }^{154}$ In fact, EXP3179 was found to promote 3T3-L1 adipocyte differentiation, induce PPAR- $\gamma$ target gene expression, and directly activate the PPAR- $\gamma-$ ligand-binding domain (LBD). EXP3174 did not induce PPAR- $\gamma-$ LBD activation and failed to regulate adipocyte differentiation of PPAR- $\gamma$ target gene expression.

\section{EFFECTS OF ATENOLOL: INTERPRETATION OF LIFE STUDY DATA}

Although the results of the LIFE study may have been due to a possible benefit of losartan other than BP control, an alternative interpretation of the LIFE data has also been put forth: the results could be partly due to lack of benefit of atenolol. In this regard, a metaanalysis of randomized trials has suggested that $\beta$-blockers (and specifically atenolol) may not provide equivalent reduction in CV events compared with other antihypertensive agents. ${ }^{155}$ The recent metaanalysis by Carlberg et al ${ }^{155}$ disputed the choice of atenolol as an appropriate comparator in clinical trials involving patients with hypertension. That analysis focused on 4 randomized trials that compared atenolol with no treatment and 5 trials that compared atenolol with other antihypertensive drugs in hypertensive patients. In the studies comparing atenolol and placebo, no differences in outcome were apparent with respect to all-cause mortality (relative risk [RR], 1.01), cardiovascular mortality (RR, 0.99), or MI (RR, 0.99); stroke risk appeared to be slightly lower in the atenolol group (RR, 0.85), but this was not statistically significant. In 5 studies comparing atenolol with other antihypertensives (HCTZ/bendroflumethiazide, captopril, losartan, or lacidipine; 17,671 patients followed over a mean of 4.6 years), a significantly higher risk of mortality (RR, 1.13 [95\% CI 1.021.25]) was found to occur with atenolol compared with the other active treatments.

These results have been challenged by a separate meta-analysis conducted by Edelman et al. ${ }^{156}$ In their meta-analysis of 6 randomized outcomes trials, a $\beta$-blocker (including atenolol-based studies, other $\beta$-blocker studies [ie, propranolol alone, atenolol/ metoprolol/pindolol combined], and diuretic-based studies in which atenolol was used as add-on therapy) was associated with a $26 \%$ risk reduction in all CV events $(P<0.001)$, a $19 \%$ risk reduction in CV death $(P=0.001)$, a $34 \%$ risk reduction in stroke $(P<0.001)$, and a $20 \%$ risk reduction in coronary heart disease $(P<0.001)$, compared with placebo or no treatment. The investigators suggested that a possible reason for the differences in findings between the 2 analyses may involve the types of study selected in each case. In this regard, it is important to note that in the meta-analysis by Carlberg et al, ${ }^{155} 2$ of the 4 studies evaluated the use of atenolol for secondary (not primary) prevention of stroke and secondary cerebroprotection.

Another possible explanation for the difference between stroke risk with losartan and atenolol observed in LIFE may involve differences in central pulse pressures between groups. ${ }^{157}$ According to results from the Anglo-Scandinavian Cardiac Outcomes Trial Conduit 
Artery Function Evaluation (ASCOT CAFE) study in hypertensive patients, ${ }^{158}$ central aortic pressures may be a better predictor of events such as stroke and MI than conventional brachial BP. ASCOT CAFE was a substudy of ASCOT and measured central and brachial BPs in 2073 hypertensive patients receiving either an amlodipine/perindopril regimen or an atenolol/ bendroflumethiazide regimen. The CAFE study found that central aortic pulse pressure was $3 \mathrm{~mm} \mathrm{Hg}$ lower in the amlodipine-based regimen than in the atenololbased regimen $(P<0.001)$, whereas brachial pulse pressure was slightly higher $(0.9 \mathrm{~mm} \mathrm{Hg})$ but not significantly different. Although these findings suggest that BP-lowering agents may have different effects on central aortic pressures, which may, in turn, translate to different clinical outcomes, it must be borne in mind that the brachial BPs were well controlled but not identical between study groups. The mean brachial diastolic BP was found to be $1.6 \mathrm{~mm} \mathrm{Hg}$ lower in patients randomized to amlodipine $(P<0.001)$. Although differences in central aortic pressures may have contributed to the stroke benefit observed in the LIFE study, ${ }^{159}$ central BP measurements were not part of the study methods. Thus, the concern cannot be confirmed or refuted.

\section{CONCLUSIONS}

A losartan-based regimen was associated with a significantly lower rate of stroke than was atenolol in hypertensive patients with LVH in the LIFE study, despite similar BP reductions. This review of the literature suggests that losartan (and perhaps other AIIAs) may possess a number of properties, independent of its antihypertensive effects, that may be associated with decreased vulnerability of the plaque, myocardium, and blood. Although some of these effects may be shared by other AIIAs or other antihypertensive classes (eg, angiotensin-converting enzyme inhibitors), some of losartan's effects appear to be molecule specific.

\section{ACKNOWLEDGMENTS}

Merck \& Co., Inc. (Whitehouse Station, New Jersey) provided financial support for this manuscript.

Dr. Díez has served as an ad hoc consultant to several pharmaceutical companies (including Merck, Novartis, Pfizer, and Roche Pharma) with commercial interests in the CV field. In the past, he has received funding for studies, seminars, and travel from these companies.
Dr. Díez thanks Tania Dickson, PhD, for her assistance with manuscript coordination and preparation and Jan S. Redfern, PhD, for editorial support.

\section{REFERENCES}

1. Cherry DK, Woodwell DA. National Ambulatory Medical Care Survey: 2000 summary. Adv Data. 2002;328:1-32.

2. Kjeldsen SE, Julius S, Hedner T, Hansson L. Stroke is more common than myocardial infarction in hypertension: Analysis based on 11 major randomized intervention trials. Blood Press. 2001;10:190-192.

3. Dunbabin DW, Sandercock PA. Preventing stroke by the modification of risk factors. Stroke. 1990;21(Suppl):IV36IV39.

4. Lewington S, Clarke R, Qizilbash N, et al. Age-specific relevance of usual blood pressure to vascular mortality: A meta-analysis of individual data for one million adults in 61 prospective studies [published correction appears in Lancet. 2003;361:1060]. Lancet. 2002;360:1903-1913.

5. Dahlof B, Devereux RB, Kjeldsen SE, et al, for the LIFE Study Group. Cardiovascular morbidity and mortality in the Losartan Intervention For Endpoint reduction in hypertension study (LIFE): A randomised trial against atenolol. Lancet. 2002;359:995-1003.

6. Kizer JR, Dahlof B, Kjeldsen SE, et al. Stroke reduction in hypertensive adults with cardiac hypertrophy randomized to losartan versus atenolol: The Losartan Intervention For Endpoint reduction in hypertension study. Hypertension. 2005;45:46-52.

7. Naghavi M, Libby $P$, Falk E, et al. From vulnerable plaque to vulnerable patient: A call for new definitions and risk assessment strategies: Part II. Circulation. 2003;108:17721778.

8. Naghavi M, Libby P, Falk E, et al. From vulnerable plaque to vulnerable patient: A call for new definitions and risk assessment strategies: Part I. Circulation. 2003;108:16641672.

9. Ross R. Atherosclerosis is an inflammatory disease. Am Heart J. 1999;138:S419-S420.

10. Glagov S, Zarins C, Giddens DP, Ku DN. Hemodynamics and atherosclerosis. Insights and perspectives gained from studies of human arteries. Arch Pathol Lab Med. 1988;112: 1018-1031.

11. Faggiotto A, Ross R, Harker L. Studies of hypercholesterolemia in the nonhuman primate. I. Changes that lead to fatty streak formation. Arteriosclerosis. 1984;4:323-340.

12. Ross R. The pathogenesis of atherosclerosis: A perspective for the 1990s. Nature. 1993;362:801-809.

13. Harrison DG. Cellular and molecular mechanisms of endothelial cell dysfunction. J Clin Invest. 1997;100:2153-2157.

14. Prasad A, Halcox JP, Waclawiw MA, Quyyumi AA. Angiotensin type 1 receptor antagonism reverses abnor- 
mal coronary vasomotion in atherosclerosis. J Am Coll Cardiol. 2001;38: 1089-1095.

15. Prasad A, Tupas-Habib T, Schenke $\mathrm{WH}$, et al. Acute and chronic angiotensin-1 receptor antagonism reverses endothelial dysfunction in atherosclerosis. Circulation. 2000;101: 2349-2354.

16. Wassmann $S$, Hilgers $S$, Laufs $U$, et al. Angiotensin II type 1 receptor antagonism improves hypercholesterolemia-associated endothelial dysfunction. Arterioscler Thromb Vasc Biol. 2002;22:1208-1212.

17. Koh KK, Ahn JY, Han SH, et al. Pleiotropic effects of angiotensin II receptor blocker in hypertensive $\mathrm{pa}^{-}$ tients. J Am Coll Cardiol. 2003;42:905910.

18. Pastore L, Tessitore A, Martinotti S, et al. Angiotensin II stimulates intercellular adhesion molecule- 1 (ICAM-1) expression by human vascular endothelial cells and increases soluble ICAM-1 release in vivo. Circulation. 1999;100:1646-1652.

19. Chobanian AV. 1989 Corcoran lecture: Adaptive and maladaptive responses of the arterial wall to hypertension. Hypertension. 1990;15: 666-674.

20. Blankenhorn DH, Hodis HN. George Lyman Duff Memorial Lecture. Arterial imaging and atherosclerosis reversal. Arterioscler Thromb. 1994;14: 177-192.

21. Hodis HN, MackWJ, LaBree L, et al. The role of carotid arterial intimamedia thickness in predicting clinical coronary events. Ann Intern Med. 1998;128:262-269.

22. Chen HJ, Li DY, Saldeen T, et al. Attenuation of tissue $\mathrm{P}$-selectin and MCP-1 expression and intimal proliferation by $\mathrm{AT}(1)$ receptor blockade in hyperlipidemic rabbits. Biochem Biophys Res Commun. 2001;282:474479.

23. Schiffrin EL, Park JB, Intengan HD, Touyz RM. Correction of arterial structure and endothelial dysfunction in human essential hyperten- sion by the angiotensin receptor antagonist losartan. Circulation. 2000; 101:1653-1659.

24. Schiffrin EL. Vascular changes in hypertension in response to drug treatment: Effects of angiotensin receptor blockers. Can J Cardiol. 2002; 18(Suppl A):15A-18A.

25. Alexander RW. Theodore Cooper Memorial Lecture. Hypertension and the pathogenesis of atherosclerosis. Oxidative stress and the mediation of arterial inflammatory response: A new perspective. Hypertension. 1995;25:155-161.

26. Keidar S, Attias J, Heinrich R, et al. Angiotensin II atherogenicity in apolipoprotein E deficient mice is associated with increased cellular cholesterol biosynthesis. Atherosclerosis. 1999;146:249-257.

27. Griendling KK, Minieri CA, Ollerenshaw JD, Alexander RW. Angiotensin II stimulates NADH and $\mathrm{NADPH}$ oxidase activity in cultured vascular smooth muscle cells. Circ Res. 1994;74:1141-1148.

28. Ushio-Fukai M, Zafari AM, Fukui T, et al. p22phox is a critical component of the superoxide-generating $\mathrm{NADH} / \mathrm{NADPH}$ oxidase system and regulates angiotensin II-induced hypertrophy in vascular smooth muscle cells. J Biol Chem. 1996;271:2331723321.

29. Zhang H, Schmeisser A, Garlichs CD, et al. Angiotensin II-induced superoxide anion generation in human vascular endothelial cells: Role of membrane-bound NADH-/NADPHoxidases. Cardiovasc Res. 1999;44:215222.

30. Sun $Y P$, Zhu $B Q$, Browne $A E$, et al. Comparative effects of ACE inhibitors and an angiotensin receptor blocker on atherosclerosis and vascular function. J Cardiovasc Pharmacol Ther. 2001;6:175-181.

31. Hayek T, Attias J, Coleman R, et al. The angiotensin-converting enzyme inhibitor, fosinopril, and the angiotensin II receptor antagonist, losartan, inhibit LDL oxidation and at- tenuate atherosclerosis independent of lowering blood pressure in apolipoprotein E deficient mice. Cardiovasc Res. 1999;44:579-587.

32. Strawn WB, Chappell MC, Dean $\mathrm{RH}$, et al. Inhibition of early atherogenesis by losartan in monkeys with diet-induced hypercholesterolemia. Circulation. 2000;101:1586-1593.

33. Rachmani R, Levi Z, Zadok BS, Ravid $M$. Losartan and lercanidipine attenuate low-density lipoprotein oxidation in patients with hypertension and type 2 diabetes mellitus: A randomized, prospective crossover study. Clin Pharmacol Ther. 2002;72:302-307.

34. Li DY, Zhang YC, Philips MI, et al. Upregulation of endothelial receptor for oxidized low-density lipoprotein (LOX-1) in cultured human coronary artery endothelial cells by angiotensin II type 1 receptor activation. Circ Res. 1999;84:1043-1049.

35. Morawietz $H$, Rueckschloss $U$, Niemann $B$, et al. Angiotensin II induces LOX-1, the human endothelial receptor for oxidized low-density lipoprotein. Circulation. 1999;100: 899-902.

36. Chen $H$, Li $D$, Sawamura $T$, et al. Upregulation of LOX-1 expression in aorta of hypercholesterolemic rabbits: Modulation by losartan. Biochem Biophys Res Commun. 2000;276:11001104.

37. Hayek T, Aviram M, Heinrich R, et al. Losartan inhibits cellular uptake of oxidized LDL by monocytemacrophages from hypercholesterolemic patients. Biochem Biophys Res Commun. 2000;273:417-420.

38. Yildirir A, Batur MK, Oto A. Hypertension and arrhythmia: Blood pressure control and beyond. Europace. 2002;4:175-182.

39. Ghali JK, Kadakia S, Cooper RS, Liao YL. Impact of left ventricular hypertrophy on ventricular arrhythmias in the absence of coronary artery disease. J Am Coll Cardiol. 1991; 17:1277-1282.

40. Oikarinen L, Nieminen MS, Viitasalo $\mathrm{M}$, et al. Relation of QT interval and 
QT dispersion to echocardiographic left ventricular hypertrophy and geometric pattern in hypertensive patients. The LIFE study. The Losartan Intervention For Endpoint Reduction. J Hypertens. 2001;19: 1883-1891.

41. Psaty BM, Manolio TA, Kuller LH, et al. Incidence of and risk factors for atrial fibrillation in older adults. Circulation. 1997;96:2455-2461.

42. Brilla CG, Matsubara L, Weber KT. Advanced hypertensive heart disease in spontaneously hypertensive rats. Lisinopril-mediated regression of myocardial fibrosis. Hypertension. 1996; 28:269-275.

43. Panizo A, Pardo J, Hernandez M, et al. Quinapril decreases myocardial accumulation of extracellular matrix components in spontaneously hypertensive rats. Am J Hypertens. 1995; 8:815-822.

44. Schwartzkopff B, Motz W, Frenzel $\mathrm{H}$, et al. Structural and functional alterations of the intramyocardial coronary arterioles in patients with arterial hypertension. Circulation. 1993;88:993-1003.

45. Diez J, Lopez B, Gonzalez A, Querejeta R. Clinical aspects of hypertensive myocardial fibrosis. Curr Opin Cardiol. 2001;16:328-335.

46. Lijnen $P$, Petrov $V$. Renin-angiotensin system, hypertrophy and gene expression in cardiac myocytes. $/ \mathrm{Mol}$ Cell Cardiol. 1999;31:949-970.

47. Gonzalez A, Lopez B, Querejeta R, Diez J. Regulation of myocardial fibrillar collagen by angiotensin II. A role in hypertensive heart disease? J Mol Cell Cardiol. 2002;34:1585-1593.

48. Avanza AC Jr, El Aouar LM, Mill JG. Reduction in left ventricular hypertrophy in hypertensive patients treated with enalapril, losartan or the combination of enalapril and losartan. Arq Bras Cardiol. 2000;74: 103-117.

49. Dahlof B, Zanchetti A, Diez J, et al, for the REGAAL Study Investigators. Effects of losartan and atenolol on left ventricular mass and neurohor- monal profile in patients with essential hypertension and left ventricular hypertrophy [published correction appears in J Hypertens. 2002;20:2135]. J Hypertens. 2002;20:1855-1864.

50. De Rosa ML, Cardace P, Rossi M, et al. Comparative effects of chronic ACE inhibition and AT1 receptor blocker losartan on cardiac hypertrophy and renal function in hypertensive patients. J Hum Hypertens. 2002;16:133-140.

51. Lopez B, Querejeta R, Varo N, et al. Usefulness of serum carboxy-terminal propeptide of procollagen type I in assessment of the cardioreparative ability of antihypertensive treatment in hypertensive patients. Circulation. 2001;104:286-291.

52. Martina B, Dieterle $T$, Weinbacher $M$, Battegay E. Effects of losartan titrated to losartan/hydrochlorothiazide and amlodipine on left ventricular mass in patients with mild-to-moderate hypertension. A double-blind randomized controlled study. Cardiology. 1999;92:110-114.

53. Tedesco MA, Ratti G, Aquino D, et al. Effects of losartan on hypertension and left ventricular mass: $A$ long-term study. J Hum Hypertens. 1998;12:505-510.

54. Flesch M, Hoper A, Dell'Italia L, et al. Activation and functional significance of the renin-angiotensin system in mice with cardiac restricted overexpression of tumor necrosis factor. Circulation. 2003;108:598-604.

55. Linz W, Gohlke $P$, Unger $T$, Scholkens BA. Experimental evidence for effects of ramipril on cardiac and vascular hypertrophy beyond blood pressure reduction. Arch Mal Coeur Vaiss. 1995;88:31-34.

56. Rials SJ, $X u X, W u Y$, et al. Restoration of normal ventricular electrophysiology in renovascular hypertensive rabbits after treatment with losartan. J Cardiovasc Pharmacol. 2001; 37:317-323.

57. Robert V, Heymes C, Silvestre JS, et al. Angiotensin AT1 receptor subtype as a cardiac target of aldos- terone: Role in aldosterone-saltinduced fibrosis. Hypertension. 1999;33: 981-986

58. Takeda $Y$, Yoneda $T$, Demura $M$, et al. Calcineurin inhibition attenuates mineralocorticoid-induced cardiac hypertrophy. Circulation. 2002;105: 677-679.

59. Varo N, Etayo JC, Zalba G, et al. Losartan inhibits the post-transcriptional synthesis of collagen type I and reverses left ventricular fibrosis in spontaneously hypertensive rats. J Hypertens. 1999;17:107-114.

60. Maia LN, Nicolau JC, Vitola JV, et al. Prospective evaluation comparing the effects of enalapril and losartan in left ventricular remodeling after acute myocardial infarction. Am Heart J. 2003;145:E21.

61. Patten RD, Aronovitz MJ, Einstein $M$, et al. Effects of angiotensin II receptor blockade versus angiotensinconverting-enzyme inhibition on ventricular remodelling following myocardial infarction in the mouse. Clin Sci (Lond). 2003;104:109-118.

62. Yang YJ, Tang YD, Ruan YM, et al. Comparative effects of carvedilol and losartan alone and in combination for preventing left ventricular remodeling after acute myocardial infarction in rats. Circ J. 2003;67: 159-162.

63. Zhang G, Shen $X, P u S$, et al. Comparative effects of losartan and captopril on ventricular remodeling and function after myocardial infarction in the rat. Chin Med SciJ. 1998; 13:32-36.

64. Zornoff LA, Matsubara LS, Matsubara BB, et al. Effects of losartan on ventricular remodeling in experimental infarction in rats. Arq Bras Cardiol. 2000;75:459-470.

65. Gonzalez Bosc L, Kurnjek ML, Muller A, Basso N. Effect of chronic angiotensin II inhibition on the cardiovascular system of the normal rat. Am J Hypertens. 2000;13:13011307.

66. Varo $\mathrm{N}$, Iraburu MJ, Varela $\mathrm{M}$, et al. Chronic AT(1) blockade stimulates 
extracellular collagen type I degradation and reverses myocardial $\mathrm{fi}^{-}$ brosis in spontaneously hypertensive rats. Hypertension. 2000;35:11971202.

67. Yu G, Liang X, Xie X, et al. Apoptosis, myocardial fibrosis and angiotensin II in the left ventricle of hypertensive rats treated with fosinopril or losartan. Chin Med J (Engl). 2002; 115:1287-1291.

68. Diez J, Querejeta R, Lopez B, et al. Losartan-dependent regression of myocardial fibrosis is associated with reduction of left ventricular chamber stiffness in hypertensive patients. Circulation. 2002;105:25122517.

69. Okin PM, Devereux RB, Jern S, et al, for the Losartan Intervention for Endpoint Reduction in Hypertension Study Investigators. Regression of electrocardiographic left ventricular hypertrophy by losartan versus atenolol: The Losartan Intervention for Endpoint Reduction in Hypertension (LIFE) Study. Circulation. 2003;108:684-690.

70. Devereux RB, Dahlof B, Gerdts E, et al. Regression of hypertensive left ventricular hypertrophy by losartan compared with atenolol: The Losartan Intervention for Endpoint Reduction in Hypertension (LIFE) trial. Circulation. 2004;110:14561462.

71. Sandmann $S$, Yu $M$, Unger $T$. Transcriptional and translational regulation of calpain in the rat heart after myocardial infarction-effects of AT(1) and AT(2) receptor antagonists and ACE inhibitor. $\mathrm{Br} J$ Pharmacol. 2001;132:767-777.

72. Sun Y, Zhang J, Lu L, et al. Tissue angiotensin $I I$ in the regulation of inflammatory and fibrogenic components of repair in the rat heart. J Lab Clin Med. 2004;143:41-51.

73. Brown L, Duce B, Miric G, Sernia C. Reversal of cardiac fibrosis in deoxycorticosterone acetate-salt hypertensive rats by inhibition of the renin-angiotensin system. J Am Soc
Nephrol. 1999;10(Suppl 11):S143S148.

74. Hara K, Kobayashi N, Nakano S, et al. Effects of TCV-116 on endothelin-1 and PDGF A-chain expression in angiotensin II-induced hypertensive rats. Hypertens Res. 2001;24:55-64.

75. Ikeda $\mathrm{Y}$, Nakamura $\mathrm{T}$, Takano $\mathrm{H}$, et al. Angiotensin II-induced cardiomyocyte hypertrophy and cardiac fibrosis in stroke-prone spontaneously hypertensive rats. J Lab Clin Med. 2000;135:353-359.

76. Kobayashi N, Nakano S, Mita S, et al. Involvement of Rho-kinase pathway for angiotensin II-induced plasminogen activator inhibitor-1 gene expression and cardiovascular remodeling in hypertensive rats. J Pharmacol Exp Ther. 2002;301:459-466.

77. Nagata K, Somura F, Obata K, et al. AT1 receptor blockade reduces cardiac calcineurin activity in hypertensive rats. Hypertension. 2002;40:168174.

78. Yamazaki T, Komuro I, Yazaki Y. Role of the renin-angiotensin system in cardiac hypertrophy. Am J Cardiol. 1999;83:53H-57H.

79. Brilla CG, Scheer C, Rupp H. Reninangiotensin system and myocardial collagen matrix: Modulation of cardiac fibroblast function by angiotensin II type 1 receptor antagonism. J Hypertens Suppl. 1997;15: S13-S19.

80. Thurmann PA, Kenedi P, Schmidt A, et al. Influence of the angiotensin II antagonist valsartan on left ventricular hypertrophy in patients with essential hypertension. Circulation. 1998;98:2037-2042.

81. Brasch $\mathrm{H}$, Sieroslawski L, Dominiak P. Angiotensin II increases norepinephrine release from atria by acting on angiotensin subtype 1 receptors. Hypertension. 1993;22:699-704.

82. Hennersdorf MG, Strauer BE. Arterial hypertension and cardiac arrhythmias. J Hypertens. 2001;19: 167-177.

83. Caballero R, Delpon E, Valenzuela $C$, et al. Losartan and its metabolite
E3174 modify cardiac delayed rectifier $\mathrm{K}(+)$ currents. Circulation. 2000; 101:1199-1205.

84. Brooksby P, Robinson PJ, Segal R, et al, for the ELITE Study Group. Effects of losartan and captopril on QT dispersion in elderly patients with heart failure. Lancet. 1999;354:395-396.

85. Newby AC, Zaltsman AB. Fibrous cap formation or destruction-the critical importance of vascular smooth muscle cell proliferation, migration and matrix formation. Cardiovasc Res. 1999;41:345-360.

86. Kranzhofer R, Browatzki $M$, Schmidt J, Kubler W. Angiotensin II activates the proinflammatory transcription factor nuclear factorkappaB in human monocytes. Biochem Biophys Res Commun. 1999;257:826-828.

87. Pueyo ME, Gonzalez W, Nicoletti A, et al. Angiotensin II stimulates endothelial vascular cell adhesion molecule-1 via nuclear factor-kappaB activation induced by intracellular oxidative stress. Arterioscler Thromb Vasc Biol. 2000;20:645-651.

88. Chen H, Li D, Mehta JL. Modulation of matrix metalloproteinase-1, its tissue inhibitor, and nuclear factorkappa B by losartan in hypercholesterolemic rabbits. J Cardiovasc Pharmacol. 2002;39:332-339.

89. Capers Q IV, Alexander RW, Lou P, et al. Monocyte chemoattractant protein-1 expression in aortic tissues of hypertensive rats. Hypertension. 1997;30:1397-1402.

90. Han KH, Tangirala RK, Green SR, Quehenberger $\mathrm{O}$. Chemokine receptor CCR2 expression and monocyte chemoattractant protein-1-mediated chemotaxis in human monocytes. A regulatory role for plasma LDL. Arteriosder Thromb Vasc Biol. 1998;18: 1983-1991.

91. Tummala PE, Chen XL, Sundell CL, et al. Angiotensin II induces vascular cell adhesion molecule- 1 expression in rat vasculature: A potential link between the renin-angiotensin system and atherosclerosis. Circulation. 1999;100:1223-1229. 
92. Kim JA, Berliner JA, Nadler JL. Angiotensin II increases monocyte binding to endothelial cells. Biochem Biophys Res Commun. 1996;226:862868.

93. Proudfoot JM, Croft KD, Puddey IB, Beilin LJ. Angiotensin II type 1 receptor antagonists inhibit basal as well as low-density lipoprotein and platelet-activating factorstimulated human monocyte chemoattractant protein-1. J Pharmacol Exp Ther. 2003;305:846-853.

94. Chen XL, Tummala PE, Olbrych $M T$, et al. Angiotensin II induces monocyte chemoattractant protein-1 gene expression in rat vascular smooth muscle cells. Circ Res. 1998; 83:952-959.

95. Rajagopalan S, Brook R, Mehta $\mathrm{RH}$, et al. Effect of losartan in agingrelated endothelial impairment. Am J Cardiol. 2002;89:562-566.

96. Dol F, Martin G, Staels B, et al. Angiotensin AT1 receptor antagonist irbesartan decreases lesion size, chemokine expression, and macrophage accumulation in apolipoprotein E-deficient mice. J Cardiovasc Pharmacol. 2001;38: 395-405.

97. Patrono C, Coller B, Dalen JE, et al. Platelet-active drugs: The relationships among dose, effectiveness, and side effects. Chest. 2001;119 (Suppl 1):39S-63S.

98. Smith WL, Langenbach R. Why there are two cyclooxygenase isozymes. J Clin Invest. 2001;107: 1491-1495.

99. Cipollone F, Rocca B, Patrono C. Cyclooxygenase-2 expression and inhibition in atherothrombosis. Arterioscler Thromb Vasc Biol. 2004; 24:246-255.

100. Ohnaka K, Numaguchi K, Yamakawa $\mathrm{T}$, Inagami T. Induction of cyclooxygenase-2 by angiotensin II in cultured rat vascular smooth muscle cells. Hypertension. 2000;35: 68-75.

101. Hu ZW, Kerb R, Shi $X Y$, et al. Angiotensin II increases expression of cyclooxygenase-2: Implications for the function of vascular smooth muscle cells. J Pharmacol Exp Ther. 2002;303:563-573.

102. Cipollone F, Fazia M, lezzi $A$, et al. Blockade of the angiotensin II type 1 receptor stabilizes atherosclerotic plaques in humans by inhibiting prostaglandin E2-dependent matrix metalloproteinase activity. Circulation. 2004;109:1482-1488.

103. Edgington TS, Mackman N, Brand K, Ruf W. The structural biology of expression and function of tissue factor. Thromb Haemost. 1991;66:67-79.

104. Wilcox JN, Smith KM, Schwartz SM, Gordon D. Localization of tissue factor in the normal vessel wall and in the atherosclerotic plaque. Proc Natl Acad Sci U S A. 1989;86: 2839-2843.

105. Nishimura $H$, Tsuji $H$, Masuda $H$, et al. Angiotensin II increases plasminogen activator inhibitor- 1 and tissue factor mRNA expression without changing that of tissue type plasminogen activator or tissue factor pathway inhibitor in cultured rat aortic endothelial cells. Thromb Haemost. 1997;77:11891195.

106. Taubman MB, Marmur JD, Rosenfield $C L$, et al. Agonist-mediated tissue factor expression in cultured vascular smooth muscle cells. Role of $\mathrm{Ca} 2+$ mobilization and protein kinase $C$ activation. J Clin Invest. 1993;91:547-552.

107. Napoleone E, Di Santo A, Camera $M$, et al. Angiotensin-converting enzyme inhibitors downregulate tissue factor synthesis in monocytes. Circ Res. 2000;86:139-143.

108. Dechend $\mathrm{R}$, Homuth $\mathrm{V}$, Wallukat $G$, et al. AT(1) receptor agonistic antibodies from preeclamptic patients cause vascular cells to express tissue factor. Circulation. 2000;101: 2382-2387.

109. Makris TK, Stavroulakis GA, Krespi PG, et al. Fibrinolytic/hemostatic variables in arterial hypertension: Response to treatment with irbe- sartan or atenolol. Am J Hypertens. 2000;13:783-788.

110. Muller DN, Mervaala EM, Dechend $\mathrm{R}$, et al. Angiotensin II (AT(1)) receptor blockade reduces vascular tissue factor in angiotensin IIinduced cardiac vasculopathy. Am J Pathol. 2000;157:111-122.

111. Nagata K, Ishibashi T, Sakamoto $T$, et al. Effects of blockade of the renin-angiotensin system on tissue factor and plasminogen activator inhibitor- 1 synthesis in human cultured monocytes. J Hypertens. 2001; 19:775-783.

112. van Leeuwen RT, Kol A, Andreotti $F$, et al. Angiotensin II increases plasminogen activator inhibitor type 1 and tissue-type plasminogen activator messenger RNA in cultured rat aortic smooth muscle cells. Circulation. 1994;90:362-368.

113. Brown NJ, Kumar S, Painter CA, Vaughan DE. ACE inhibition versus angiotensin type 1 receptor antagonism: Differential effects on PAl-1 over time. Hypertension. 2002;40: 859-865.

114. Erdem $Y$, Usalan C, Haznedaroglu $I C$, et al. Effects of angiotensin converting enzyme and angiotensin II receptor inhibition on impaired fibrinolysis in systemic hypertension. Am J Hypertens. 1999;12:10711076.

115. Ma LJ, Nakamura S, Whitsitt JS, et al. Regression of sclerosis in aging by an angiotensin inhibitioninduced decrease in PAl-1. Kidney Int. 2000;58:2425-2436.

116. Papakonstantinou $E$, Roth $M$, Kokkas B, et al. Losartan inhibits the angiotensin II-induced modifications on fibrinolysis and matrix deposition by primary human vascular smooth muscle cells. J Cardiovasc Pharmacol. 2001;38:715-728.

117. Saito M, Kawasaki S, Hashiba T, et al. Effects of losartan, an angiotensin II receptor antagonist, on the fibrinolytic system in hypertensive patients. Int J Hematol. 1999;70: 60-61. 
118. Fogari R, Derosa G, Mugellini A, et al. Effect of losartan, irbesartan, and candesartan on platelet aggregability and fibrinolysis in type 2 diabetic hypertensive patients. J Hypertens. 2003;21(Suppl 4):S85. Abstract.

119. Levy PJ, Yunis C, Owen J, et al. Inhibition of platelet aggregability by losartan in essential hypertension. Am J Cardiol. 2000;86:11881192.

120. Chen HC, Bouchie JL, Perez AS, et al. Role of the angiotensin AT(1) receptor in rat aortic and cardiac PAI-1 gene expression. Arterioscler Thromb Vasc Biol. 2000;20:22972302.

121. Oubina MP, de Las Heras $N$, Vazquez-Perez $S$, et al. Valsartan improves fibrinolytic balance in atherosclerotic rabbits. $\int$ Hypertens. 2002;20:303-310.

122. Gresele P, Deckmyn H, Nenci GG, Vermylen J. Thromboxane synthase inhibitors, thromboxane receptor antagonists and dual blockers in thrombotic disorders. Trends Pharmacol Sci. 1991;12:158-163.

123. Jagroop IA, Mikhailidis DP. Angiotensin II can induce and potentiate shape change in human platelets: Effect of losartan. J Hum Hypertens. 2000;14:581-585.

124. Buczko W, Matys T, Pawlak R, et al. Studies on the antithrombotic action of AT1 receptor antagonists. Med Sci Monit. 2001;7:600-605.

125. Chabielska E, Pawlak R, Golatowski J, et al. Losartan inhibits experimental venous thrombosis in spontaneously hypertensive rats. Thromb Res. 1998;90:271278.

126. Chlopicki S, Koda M, Chabielska $E$, et al. Antiplatelet action of losartan involves TXA2 receptor antagonism but not TXA2 synthase inhibition. J Physiol Pharmacol. 2000;51:715-722.

127. Guerra-Cuesta JI, Monton M, Rodriguez-Feo JA, et al. Effect of losartan on human platelet activation. J Hypertens. 1999;17:447-452.
128. Li P, Ferrario CM, Brosnihan KB. Losartan inhibits thromboxane A2induced platelet aggregation and vascular constriction in spontaneously hypertensive rats. J Cardiovasc Pharmacol. 1998;32:198-205.

129. Lopez-Farre A, Sanchez de Miguel $\mathrm{L}$, Monton $\mathrm{M}$, et al. Angiotensin II AT(1) receptor antagonists and platelet activation. Nephrol Dial Transplant. 2001;16(Suppl 1):45-49.

130. Nunez A, Gomez J, Zalba LR, et al. Losartan inhibits in vitro platelet activation: Comparison with candesartan and valsartan. J Renin Angiotensin Aldosterone Syst. 2000;1: 175-179.

131. Schwemmer $M$, Sommer $O$, Bassenge E. Angiotensin receptor blocker losartan suppresses platelet activity by interfering with thromboxane signaling. Cardiovasc Drugs Ther. 2001;15:301-307.

132. Kramer C, Sunkomat J, Witte J, et al. Angiotensin II receptorindependent antiinflammatory and antiaggregatory properties of losartan: Role of the active metabolite EXP3179 [published correction appears in Circ Res. 2002;91:e65]. Circ Res. 2002;90:770-776.

133. Culleton BF. Uric acid and cardiovascular disease: A renal-cardiac relationship? Curr Opin Nephrol Hypertens. 2001;10:371-375.

134. Johnson RJ, Kang DH, Feig D, et al. Is there a pathogenetic role for uric acid in hypertension and cardiovascular and renal disease? Hypertension. 2003;41:1183-1190.

135. Alderman M, Aiyer KJ. Uric acid: Role in cardiovascular disease and effects of losartan. Curr Med Res Opin. 2004;20:369-379.

136. Mustard JF, Murphy EA, Ogryzlo MA, Smythe HA. Blood coagulation and platelet economy in subjects with primary gout. Can Med Assoc J. 1963;89:1207-1211.

137. Kanellis J, Watanabe S, Li JH, et al. Uric acid stimulates monocyte chemoattractant protein-1 production in vascular smooth muscle cells via mitogen-activated protein kinase and cyclooxygenase-2. Hypertension. 2003;41:1287-1293.

138. Waring WS, Webb DJ, Maxwell SR. Effect of local hyperuricemia on endothelial function in the forearm vascular bed. Br J Clin Pharmacol. 2000;49:511. Abstract.

139. Mazzali M, Kanellis J, Han L, et al. Hyperuricemia induces a primary renal arteriolopathy in rats by a blood pressure-independent mechanism. Am J Physiol Renal Physiol. 2002;282:F991-F997.

140. Rao GN, Corson MA, Berk BC. Uric acid stimulates vascular smooth muscle cell proliferation by increasing platelet-derived growth factor A-chain expression. J Biol Chem. 1991;266:8604-8608.

141. Watanabe $S$, Kang DH, Feng $L$, et al. Uric acid, hominoid evolution, and the pathogenesis of salt-sensitivity. Hypertension. 2002;40:355-360.

142. Kang $D H$, Nakagawa $T$, Feng $L$, et al. A role for uric acid in the progression of renal disease. J Am Soc Nephrol. 2002;13:2888-2897.

143. Weir CJ, Muir SW, Walters MR, Lees KR. Serum urate as an independent predictor of poor outcome and future vascular events after acute stroke. Stroke. 2003;34: 1951-1956.

144. Nakashima M, Uematsu $T$, Kosuge K, Kanamaru M. Pilot study of the uricosuric effect of DuP-753, a new angiotensin II receptor antagonist, in healthy subjects. Eur J Clin Pharmacol. 1992;42:333-335.

145. Burnier M, Roch-Ramel F, Brunner $H R$. Renal effects of angiotensin II receptor blockade in normotensive subjects. Kidney Int. 1996;49:17871790.

146. Sweet CS, Bradstreet DC, Berman RS, et al. Pharmacodynamic activity of intravenous E-3174, an angiotensin II antagonist, in patients with essential hypertension. Am J Hypertens. 1994;7:1035-1040.

147. Ilson BE, Martin DE, Boike SC, Jorkasky DK. The effects of 


\section{Clinical Therapeutics}

eprosartan, an angiotensin II AT1 receptor antagonist, on uric acid excretion in patients with mild to moderate essential hypertension. J Clin Pharmacol. 1998;38:437-441.

148. Sayin T, Doven O, Akyurek $O$, Dincer I. Neutral effect of valsartan on serum uric acid and renal function tests. J Hum Hypertens. 2001; 15:435-436.

149. Wurzner G, Gerster JC, Chiolero A, et al. Comparative effects of losartan and irbesartan on serum uric acid in hypertensive patients with hyperuricaemia and gout.J Hypertens. 2001;19:1855-1860.

150. Hoieggen $\mathrm{A}$, Alderman $\mathrm{MH}$, Kjeldsen SE, et al, for the LIFE Study Group. The impact of serum uric acid on cardiovascular outcomes in the LIFE study. Kidney Int. 2004;65:1041-1049.

151. Stearns RA, Chakravarty PK, Chen $\mathrm{R}$, Chiu SH. Biotransformation of losartan to its active carboxylic acid metabolite in human liver microsomes. Role of cytochrome P4502C and 3A subfamily members. Drug Metab Dispos. 1995;23:207-215.

152. Lo MW, Goldberg MR, McCrea JB, et al. Pharmacokinetics of losartan, an angiotensin II receptor antagonist, and its active metabolite EXP3174 in humans. Clin Pharmacol Ther. 1995;58:641-649.

153. Watanabe T, Suzuki J, Yamawaki $\mathrm{H}$, et al. Losartan metabolite EXP3179 activates Akt and endothelial nitric oxide synthase via vascular endothelial growth factor receptor-2 in endothelial cells: Angiotensin II type 1 receptorindependent effects of EXP3179. Circulation. 2005;112:1798-1805.

154. Schupp M, Lee LD, Frost N, et al. Regulation of peroxisome proliferatoractivated receptor gamma activity by losartan metabolites. Hypertension. 2006;47:586-589.

155. Carlberg B, Samuelsson $O$, Lindholm $\mathrm{LH}$. Atenolol in hypertension: Is it a wise choice? [published correction appears in Lancet. 2005;365:656]. Lancet. 2004;364:1684-1689.
156. Edelman JM, Lyle PA, Zhang Z. In response [electronic letter]. Ann Intern Med. 2004;140:W29.

157. Safar ME, O'Rourke MF. Pulse pressure and antihypertensive agents. Hypertension. 2005;46:e6.

158. Williams B, Lacy PS, Thom SM, et al, for the CAFE Investigators, the AngloScandinavian Cardiac Outcomes Trial Investigators, and the CAFE Steering
Committee and Writing Committee. Differential impact of blood pressurelowering drugs on central aortic pressure and clinical outcomes: Principal results of the Conduit Artery Function Evaluation (CAFE) Study. Circulation. 2006;113:1213-1225.

159. Fyhrquist F, Devereux R, Kjeldsen S, Dahlof B. Response. Hypertension. 2005;46:e6-e7.

Address correspondence to: Javier Díez, MD, $\mathrm{PhD}$, Division of Cardiovascular Sciences, Centre for Applied Medical Research, and Department of Cardiology and Cardiovascular Surgery, University Clinic, School of Medicine, University of Navarra, Pio XII, 55. 31008 Pamplona, Spain. E-mail: jadimar@unav.es 